\title{
The main structural reorganization of the South Baikal Basin: Early Pliocene initiation of strong tectonic deformations and the Lena runoff from Lake Baikal
}

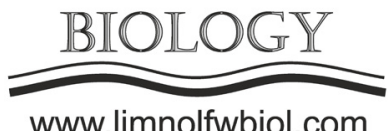

www.limnolfwbiol.com

\author{
Rasskazov S.V. ${ }^{1,2}$, Al Hamud A. ${ }^{2,3}$, Kononov E.E. ${ }^{4}$, Kolomiets V.L. ${ }^{5,6}$, Budaev R.Ts. ${ }^{5}$, \\ Hassan A. ${ }^{2,7}$, Tregub T.F. ${ }^{8}$, Kulagina N.V. ${ }^{1}$, Yasnygina T.A. ${ }^{1}$, Chuvashova I.S. ${ }^{1,2}$
}

${ }^{1}$ Institute of the Earth's Crust SB RAS, Irkutsk, Russia

${ }^{2}$ Irkutsk State University, Irkutsk, Russia

${ }^{3}$ University of Al-Furat, Deir Ez-Zor, Syria

${ }^{4}$ Institute of Geography SB RAS, Irkutsk, Russia

${ }^{5}$ Geological Institute SB RAS, Ulan-Ude, Russia

${ }^{6}$ Buryat State University, Ulan-Ude, Russia

${ }^{7}$ Al-Bass University, Homs, Syria

${ }^{8}$ Voronezh State University, Voronezh, Russia

\begin{abstract}
On the southern coast of Lake Baikal, we have recorded conformed relations between stratons from the Eocene to the Early Pliocene and overturned ones of this deformed sedimentary stratum. On the opposite coast of the lake, on the Angara-Lena watershed, we have identified the Lower Pliocene sediments in the Pra-Manzurka paleovalley. We suggest that the simultaneous initiation of strong tectonic deformations of sediments on the southern shore of the lake and the Lena runoff on its opposite shore designate the main Early Pliocene structural reorganization that led to the formation of the modern deep Baikal.
\end{abstract}

Keywords: Baikal, tectonic reorganization, sediments, Pliocene, Quaternary, palynology

\section{Introduction}

A tectonic opening of Lake Baikal basins was assumed to be initiated by sufficient left-lateral tectonic motions along the Main Sayan fault (Lamakin, 1968). From this assumption, a pattern of palinspastic reconstructions of the Baikal shore motions was proposed (Balla et al., 1990). The determination of a tectonic mechanism of the lake basins opening should be justified, however, primarily by data on the time and nature of the development of coastal erosion-accumulative processes. The aim of this study is to determine the main boundary of a structural reorganization in the South Baikal Basin that resulted in the formation of the modern deep Baikal.

\section{Research methods}

On the Baikal coasts, sedimentary strata are dissected according to lithological and stratigraphic criteria that were the basis for identifying coalbearing, red-colored, and sandy formations within the Baikal type basins (Logatchev, 1958). For more detail subdivision of the formations into packages and marking layers, sediments were analyzed for major oxides by the "wet chemistry" methods and for trace elements by the ICP-MS method. The units were dated in stratigraphic sequences using paleontological data.

\section{Results}

To determine the main structural reorganization of the South Baikal Basin, we compare sedimentary sequences of the southern coast of Lake Baikal, lying in the Mishikha-Klyuevka and Osinovka paleovalleys at the Tankhoi tectonic step (Rasskazov et al., 2014), and those of the opposite coast, lying within the PraManzurka paleovalley of the Angara-Lena watershed (Logatchev et al., 1964).

On the southern coast of Lake Baikal, a complete sequence of sediments from the Eocene to the Quaternary was studied in the Mishikha reference section of the Mishikha-Klyuevka paleovalley (Al Hamud et al., 2019). In an outcrop of sub-horizontal beds, exposed in the southern side of the road, polyfacial ocherous sediments containing the Late Eocene sporepollen spectrum was recorded lower a layer of Upper Oligocene "blue clays". Above the "blue clays" layer, 4 
more units were identified: (1) Lower Miocene (Lower Tankhoi), predominantly aleurite, with brown coal interlayers; (2) Middle-Upper Miocene (Osinovka), without coal interlayers; (3) Upper Miocene (Upper Tankhoi), sandy-silty, with fragments of "blue clays", and finally (4) two Quaternary (overlying), sandy and boulder-pebble. Unlike this outcrop, the one in the northern side of the road showed a tilted sedimentary sequence. Due to tectonic deformations, the stratum was overturned and the older layers were observed higher than the young ones. A contact was exposed between the Eocene-Upper Oligocene strata with normal stratigraphic bedding and the Eocene-Lower Pliocene one with overturned bedding.

On the northern coast of Lake Baikal, we have solved a problem of determining of a time, when the Pra-Manzurka paleovalley was formed. The earliest sediments, showed a rich Early Pliocene spore-pollen complex, were found in the new quarry Kosaya Step-3. At the base of the section, there is a layer of homogeneous well-washed coarse-grained gray sand. Above, there is gravel-sand differentiation of the material in the form of a series of oblique-bedded lenses $20-30 \mathrm{~cm}$ thick with a total thickness of up to $2 \mathrm{~m}$. This series is cut by a single diagonal surface that begins a series of large cross-bedded gravel-sand lenses extended laterally for at least $20 \mathrm{~m}$. The overlying (the second) member is composed of horizontally layered rhythmic lacustrine sediments up to $2.5 \mathrm{~m}$ thick. The layers are light brown, reddish, and gray, of primary sedimentation origin. The third member is represented by cross-bedded sands similar to those of the first one. Its thickness is the several meters. The fourth member is composed mainly of small pebbles with rare sand lenses with an apparent thickness of up to $15 \mathrm{~m}$.

The four recorded members are separated from each other by erosional surfaces. Between the first and second packages, which change relative elevation by $4-5 \mathrm{~m}$, a surface is traced by lenses of gray clays that form swells as thick as first tens of $\mathrm{cm}$. From this unconformity surface, limonitic spots penetrate into the lower package along the cracks. At the base of the lacustrine member, the unconformity surface is denoted by a lens of rubble-grit material that includes blobs of gray clays up to $20 \mathrm{~cm}$ in diameter. The same clay blobs (up to $5 \mathrm{~cm}$ ) are observed in the layers of the overlying lacustrine member. The unconformity surface between the third and fourth members is indicated by uneven contact of pebble and sands that changes elevation over 2-3 m.

\section{Discussion}

The key assumption on significant Late Cenozoic lateral displacements along the Main Sayan fault (Lamakin, 1978), taken for later palinspastic reconstruction of the Baikal opening, was not confirmed geologically, however (Rasskazov et al., 2013). Although the structural continuation of the Main Sayan fault under the lake is reflected in seismicity (Melnikova et al., 2012); it is obvious that the Late Cenozoic rapid subsidence of the South Baikal Basin, uncompensated by sediments, was in contrast with the uplift of the adjacent Tunka Rift Valley (Rasskazov et al., 2020). New data obtained on sediments of the southern and northern coasts of the Baikal provide a benchmark for assessing the time and nature of the initiation of tectonic motions that led to the basin formation for the deep Baikal.

On the northern coast of the lake, the Manzurka alluvium was described as multiple interbedding or lensing of pebbles and sands, among which thin interlayers of light kaolinite-hydromica clays are rarely found. The Kaizeran section, obtained by drilling, showed an unidirectional change in the granulometric composition of sediments from the bottom upward along the entire section. Based on the analysis of different sections, constant lithological-facies changes were inferred with gradual change of clastic material and appearance of clay-bearing rocks that corresponded to the final stage of alluvium accumulation and transition to that in lakes and swamps. The Manzurka alluvium was considered within the framework of one erosion-sedimentation cycle, that followed the formation of the Upper Pliocene-Lower Pleistocene redcolored formation, but preceded the Lower Pleistocene Anga alluvium, which was characterized by fauna of corbicles and mammals corresponding to the Tiraspol fauna assemblages. It was suggested that the Early Pleistocene runoff of waters from the Baikal to Lena was provided through the Pra-Manzurka valley and was interrupted by the uplift of the Primorskiy Ridge (Logatchev et al., 1964; Logatchev, 1974; Kononov and Mats, 1986).

The studied Kosaya Step-3 section differs from the typical ones of the Lower Pleistocene Manzurka alluvium described by Logatchev and others (1964). Variations of coarse-clastic alluvial facies, occurrence of lacustrine and again coarse-clastic alluvial sediments show two erosion-accumulative phases. The first was launched and gradually weakened due to decreasing paleoriver flow, possibly with its cessation. The second phase was designated by a resumption of a runoff with a new intensification of the alluvial processes, abruptly stopped. The sediments of the Kosaya Step3 section are dated back to the Lower Pliocene and correlate with the final layers of the coal-bearing Tankhoi suite. In addition, some outcrops of the PraManzurka paleovalley exhibite ocher alluvium that is lithologically similar to the Upper Pliocene-Lower Pleistocene red-colored Anosov Formation.

We infer that alluvial sediments of a single geomorphological level in the Pra-Manzurka paleovalley cover the time range of the runoff from Lake Baikal to Lena River from the Early Pliocene to the Early Pleistocene. This conclusion makes a particular sense related to the strong Early Pliocene deformations in the Mishikha-Klyuevka paleovalley, where a conforming accumulation of sediments took place from the Eocene to the Early Pliocene. The tectonic deformations, resulted in the overturned beds in the Mishikha section, occurred at a critical phase in the development of the South Baikal Basin. 
Eocene and Oligocene sediments of the lower part of the Mishikha section correlate with those of the Irenga and Kularikta formations in the SelengaVitim foredeep, whereas the Miocene-Lower Pliocene sediments of the upper part of the section correspond to the development of basins in the Baikal Rift System. In the Osinovka paleovalley of the Tankhoi tectonic step, only the sediments of the South Baikal Basin accumulated that indicates the beginning of its subsidence in the Early Miocene. Due to the Early Pliocene tectonic deformations, the Mishikha-Klyuevka paleovalley uplifted, unlike the Osinovka one that occupied the lower level in relief resulted in sediment accumulation throughout the Pliocene and Early Pleistocene (Rasskazov et al., 2014).

\section{Conclusion}

The findings of evidence on strong Early Pliocene deformations of sediments in the MishikhaKlyuevka paleovalley and the identified Lower Pliocene sediments in the Pra-Manzurka paleovalley lead to the conclusion about the Early Pliocene turning point in the development of the South Baikal Basin. The PraManzurka runoff from Lake Baikal began at this time and existed with interruptions until the uplift of the Primorsky ridge that occurred at the beginning of the Middle Pleistocene. The Early Pliocene events designate the main boundary of tectonic reorganization that led to the formation of the modern deep Baikal.

This work was supported by the Russian Science Foundation (grant 18-77-10027).

\section{References}

Al Hamoud A., Rasskazov S.V., Chuvashova I.S. et al. 2019. Temporal compositional variations of Cenozoic sediments on the Tankhoi tectonic step, the Southern Baikal. Irkutsk State University Bulletin. Earth Science Series 30: 108-129.

Balla Z., Kuzmin M.I., Levi K.G. 1990. Kinematics of the Baikal opening. Geotectonics 2: 80-91.

Kononov E.E., Matz V.D. 1986. History of Lake Baikal runoff. Izvestiya of Universities. Geology and exploration 6: 91-98. (In Russian)

Lamakin V.V. 1968. Neotectonics of the Baikal basin. Moscow: Nauka. (Transactions of Geological Institute, vol. 187). (In Russian)

Logatchev N.A. 1958. Cenozoic continental deposits of the Baikal-type basins. Izvestiya of USSR Academy of Science. Geological series 4: 18-29. (In Russian)

Logatchev N.A. 1974. Sayan-Baikal and Stanovoy uplands. Uplands of Pribaikal and Transbaikal. Moscow: Nauka. (In Russian)

Logatchev N.A., Lomonosova T.K., Klimanova V.M. 1964. Cenozoic sediments of the Irkutsk amphitheater. Moscow: Nauka Publishing house. (In Russian)

Melnikova V.I., Gileva N.A., Arefyev S.S. et al. 2012. The Kultuk 2008 earthquake with $\mathrm{Mw}=6.3$ in the south of Baikal: spatial-temporal analysis of seismic activation. Izvestiya. Physics of the Solid Earth 7: 594-614.

Rasskazov S., Ilyasova A., Bornyakov S. et al. 2020. Responses of a ${ }^{234} \mathrm{U} /{ }^{238} \mathrm{U}$ activity ratio in groundwater to earthquakes in the South Baikal Basin, Siberia. Frontiers in Earth Sciencedoi.org/10.1007/s11707-020-0821-5

Rasskazov S.V., Lyamina N.A., Luzina I.V. et al. 2014. Sediments in the Tertiary Tankhoi field, South Baikal Basin: stratigraphy, correlation and structural transformations in the Baikal region. Geodynamics \& Tectonophysics 5(4): 993-1032.

Rasskazov S.V., Yasnygina T.A., Chuvashova I.S. et al. 2013. The Kultuk Volcano: spatial-temporal change of magmatic sources at the western terminus of the South Baikal basin between 18 and 12 Ma. Geodynamics \& Tectonophysics 4(2): 135-168. 